Zagadnienia Rodzajów Literackich, LX, z. 2

PL ISSN 0084-4446

DOI: $10.26485 / Z R L / 2017 / 60.2 / 6$

BARBARA SZOT

Univerzity Palackého*

\title{
Parodied Locations: A Play on Genre Conventions and Place in Flann O'Brien's The Poor Mouth and Alasdair Gray's Poor Things
}

\begin{abstract}
Flann O'Brien in The Poor Mouth and Alasdair Gray in Poor Things use parody (of Gaeltacht memoirs and Gothic fiction respectively) to join in a discussion on literary representations of their homelands (Ireland and Scotland). This paper discusses the subversive play on the reader's expectations regarding literary representation of places driven by previous knowledge of the parodied genre's conventions which the two authors use to pinpoint the inadequacy of the hitherto existing literary tradition.
\end{abstract}


* Katedra anglistiky a amerikanistiky

Filozofická fakulta

Třída Svobody 26, Olomouc 771 80, Czech Republic e-mail: barbara.szot02@upol.cz

This article was written within the project IGA_FF_2016_058, financed from the budget provided in 2016 by the Ministry of Education, Youth and Sports of the Czech Republic to Palacký University Olomouc to support specific research activities at the university. 
One of the things Flann O'Brien ${ }^{1}$ and Alasdair Gray have in common is their preoccupation with other authors' narratives. Both debuted as novelists with overtly intertextual works, O’Brien with At Swim-Two-Birds in 1939 and Gray with Lanark in 1981, embroidered with a wide range of literary references. O'Brien's The Poor Mouth and Gray's Poor Things are likewise rich in allusions to other works. The Poor Mouth (published in Irish in 1941 as An Béal Bocht and translated to English by Patrick C. Power in 1973) parodies the Gaeltacht autobiographies extensively published in Ireland in the 1920s and 1930s. Poor Things is, in Alan Riach's description, 'a neo-Gothic-quasi-Victorian-satiric-pastiche selfdiscovery mystery story’ (Riach 2014: 163) which re-writes Mary Shelley's Frankensteinian plot with references to other iconic Gothic works (by Poe, Stoker, or Stevenson). 'What morbid Victorian fantasy has he NOT filched from?’ we find Victoria McCandles/Bella Baxter, the central female character, ask in a letter which aims to undermine the authenticity of the main narrative written by her husband (Gray 1993: 272-273). Both novels thus address a certain genre convention making it the epicentral point of intertextual reference.

The aim of this paper is to discuss how O'Brien's and Gray's use of spatial frames they construct for their narratives corresponds to that choice and how they use the convention to make a point about actual places (Gaeltacht/Ireland and Glasgow/Scotland). Genette argues that 'generic perception is known to guide and determine to a considerable degree the readers' expectations' (Genette 1997: 5). Engaging the readers in an intertextual play which addresses their genre-driven expectations, the two authors create an interface between experiment-fuelled postmodern literature and an orientation towards regionalism which results in renegotiation of literary representations of space.

Daniela Hodrová argues in her introduction to Poetika mist that place in fiction is closely interlinked to the genre (Hodrová 1997: 15). This is especially true, she notes, in the case of folk-tales and plot-driven genre fiction where the genre often predetermines certain locations to host certain plot events. Both adhering to the archetypical function a place has

1 "Flann O'Brien" is used in this paper as it is under this name that the English translation of An Béal Bocht tends to be published. The Irish version of the novel, however, was written under the penname Myles na gCopaleen. The Tale of Black Peter (also originally written in Irish as Aistear Pheadair Dhuibh and also referred to in this paper) has first been published under the author's actual name (spelt in Irish), Brian Ó Nualláin (English version: Brian O’Nolan). 
in a specific genre and subverting the traditional representation produce a specific artistic effect. The structure of the literary place is multi-aspectual but especially in the more conventionalized genres it tends to gravitate towards one particular function that dominates in a given work. The 'artistic' genres, as Hodrová calls them, on the other hand often engage in the process of constant re-evaluation of the meaning of the place but that is only possible againts the stability provided by the 'memory of the genre' (Hodrová 1997: 15-16).

O'Brien and Gray with their habitual subversiveness and love for experiment belong at the 'artistic' end of the literary spectrum. But the type of fiction they pastiche in The Poor Mouth and Poor Things does not. Moreover, they are types of fiction that strongly associate certain topography. Definitions of the Gothic novel usually name the typical locations where the Gothic plots are set (cf. Cuddon 2013: 308, Bigsby 2006: 100) making it one of the most conventionalised genres in that respect. The setting of the sources mimicked in The Poor Mouth is even more distinct. O'Brien parodies the Irish-language autobiographies/ memoirs from the Gaeltacht (i.e. the Irish-speaking regions in Ireland), the most famous of which came from the inhabitants of the Blasket Islands. As these books are non-fiction writing produced in close proximity to each other, both timewise and geographically, they are bound to be set in similar locations. However actual these locations once were, with the Blaskets being a remote location and their population already heavily in decline at the time of the publishing (the islands were altogether abandoned by the mid-1950s) they were particularly predisposed to be mythologised by the reading public. The way in which these narratives have become the conventional way of representing the Gaeltacht is one of the main targets of O'Brien's satire, not only in The Poor Mouth. The parodies of The Poor Mouth and Poor Things thus both spring from literary templates which are to a large degree characterised by their topographies. This provides the stability which enables the 'artistic' experiments carried out on literary places.

Linda Hutcheon argues that parody 'is a form of imitation characterized by ironic inversion, not always at the expense of the parodied text. (...) (a) repetition with critical distance which marks difference rather than similarity' (Hutcheon 1986: 6). Her definition of parody in A Theory of Parody: The Teachings of Twentieth-Century Art Forms derives from, as the subtitle suggests, the actual practices of the $20^{\text {th }}$ century authors, that is the practices of Alasdair Gray and Flann O'Brien as well (both are referred to in Hutcheon's work). It goes against the traditional notion of defining parody through its polemical relation to what Genette calls the hypotext. Although not as willing as Hutcheon to altogether disregard the polemics factor, Simon Dentith in his 'inclusive definition' of parody argues that 'the polemical allusive imitation of a preceding text that characterises parody can have its polemic directed to the world rather than the preceding text' (Dentith 2000: 18). In that light, both The Poor Mouth and Poor Things deserve to be labelled as parodies though neither is merely set to ridicule the texts they draw upon.

Carol Taaffe notes on The Poor Mouth: 'While An Béal Bocht most famously parodies Ó Criomhthain's An tOileánach, O’Nolan's respect for his target text is equally well acknowledged. It might be more accurate to say that his novel targets imitations by less able writers, but its satire is more generally directed at the very fashion for the genre itself' (Taaffe 2008: 103). The fashion referred to was not the reading public's arbitrary fad. It was the newly established Irish state's policy to publish and promote Gaelic books merely because they were Gaelic, with no concern for the quality of anything but the language 
itself, a practice O'Brien strongly opposed (Farnon 1997: 89-90). His use of a framing device of an editor who introduces the memoir-like narrative and glosses the Anglicisms appearing in the allegedly true Gael's narrative with their 'truer' Irish versions together with his harshly sarcastic representations of non-Gaeltacht Irish language enthusiasts are clear hints that the satire is aimed more so at the cultural policy makers and the uncritical enthusiasts of those policies. Alasdair Gray's attitude towards the texts he mimics is even more amicable. The iconic Frankensteinian plot is certainly the most easily traceable reference and the one most minutely crafted with details of Mary Shelley's life woven into the narrative (Stirling 2008: 92) and it is hardly executed with an attempt to ridicule the source narrative. Allusions to Scottish writers also seem to be an attempt to amplify the status of the original works rather than to lessen it. The interest in Scottish literature began to arise in the late 1970s and grew throughout the 1980s. Douglas Gifford notes, 'many Scottish writers began to explore the possibilities of exploiting a new awareness of Scottish literary genre and fictional tradition. Alasdair Gray would do this outstandingly in Poor Things (1992) and A History Maker (1994) (exploiting Stevenson and Hogg respectively)' (Gifford 2002: 900-901). Instead of being an assault on the literary models of Poor Things, its satire and polemic are aimed at social and gender inequalities and British imperialism. Stirling notes, 'There are many other paths of enquiry to pursue in Poor Things, and because of its multi-layered narratives it is able to support - and indeed encourage - a number of different readings and interpretations' (Stirling 2008: 89). Scottish identity is one major theme explored by Gray in his novel. Although one could argue that he often approaches this theme with 'ironic inversion' and 'critical distance' Hutcheon names as prerequisites for parody, it would be hard to pinpoint any particular version of Scottishness or unScottishness which is being parodied or satirized.

While O'Brien mocked a certain cultural/national policy regarding the construction of Irish identity, Gray half a century later is engaged in an act of constructing the discourse on the Scottish identity. In a much quoted fragment of Lanark, Gray's debut and most famous novel, we find the protagonist state:

think of Florence, Paris, London, New York. Nobody visiting them for the first time is a stranger because he's already visited them in paintings, novels, history books and films. But if a city hasn't been used by an artist not even the inhabitants live there imaginatively. What is Glasgow to most of us? A house, the place we work, a football park or golf course, some pubs and connecting streets. That's all. (...) Imaginatively Glasgow exists as a music-hall song and a few bad novels. That's all we've given to the world outside. It's all we've given to ourselves.

(Gray 1984: 243)

The theme of imaginative representation of real-life world locations is something O'Brien addresses in his 1933 Gaeltacht-based short story The Tale of Black Peter. ${ }^{2}$ The main protagonist after exercising a daily Gaeltacht routine of putting on an Aran jumper, eating a poor breakfast of nettles and saying his prayers goes out to asks the local priest: 'Tell me this much: WHO CREATED ME AND THIS MISERABLE COUNTRY?' to which he receives the answer 'God didn't create it (...) It was Parthalán Mac an Dubhdha, author, and Feidhlimídh Ó Casaidhe, poet-both natives of Dublin’ (O’Brien 2013: 30). These

2 Originally published in Irish as Aistear Pheadair Dhuibh. 
fragments reveal that Gaeltacht, which at the time of O'Brien's writing often stood for the true Ireland, already had a substantial body of literature set in it; a body distinct enough to be parodied in a fairly direct way. Glasgow on the other hand was still very much underrepresented in literary works almost half a century later. In other words, while O'Brien is already at the business of renegotiating the representation of Ireland, Gray is still engaged with trying to put Glasgow, and Scotland in general, on the map. Generally, The Poor Mouth with its somewhat narrower scope of intertextual reference (the Gaeltacht memoirs of the 1920s and 1930s which serve as the starting point of implicit criticism of cultural and national policies of the time) seems to be easily classifiable as a parody under any definition of the term whereas Poor Things with the much more extensive field of literary allusions and real-world issues it addresses require broader understanding of the term that Hutcheon and Dentith offer. When the location factor is considered, O'Brien sets his narrative where the parodied texts have set theirs which allows a fairly straightforwardly parodic depiction to be carried out. Gray, on the other hand, implants a genre which calls for certain locations onto a location which is rather incompatible with that genre (as industrial cities like Glasgow hardly constitute an archetypally Gothic setting) and had generally not excited writers' imagination thus far.

The Poor Mouth is a first-person account of the life of Bonaparte O'Coonassa, born and raised in a fictional Gaeltacht village of Corca Dorcha ${ }^{3}$ where he lives in a small house with his mother, his grandfather Old-Grey-Fellow ${ }^{4}$, and their livestock. Their existence is heavily marked with poverty, bad weather and pig stench. The vast majority of events are either extracted from stereotypical Gaeltacht memoirs (and then pushed to absurdity) or drafted to ridicule the city-based linguists/folklorists and the unrealistic ideas they have about the objects of their interest.

When describing his house the narrator, writes: 'We lived in a small, lime-white, unhealthy house, situated in a corner of the glen on the right-hand side as you go eastwards along the road' (O'Brien 2007: 416). Then he adds: 'It has always been the destiny of the true Gaels (if the books be credible) to live in a small, lime-white house in the corner of the glen as you go eastwards along the road and that must be the explanation that when I reached this life there was no good habitation for me but the reverse in all truth' (O’Brien 2007: 416). Exactly what books are referred to is explained earlier on. In a scene which the narrator states happened on a 'day of my youth which is clear in my memory and eminently describable’ (O’Brien 2007: 415), we find his mother sweeping the house and the grandfather objecting to that. He tells the mother: 'when I was a youngster growing up, I was (as is clear to any reader of good Gaelic books) a child among the ashes' and he condemns her for sweeping the ashes out to the yard arguing it is 'an unnatural and unregulated training and rearing he'll have without the experience of the ashes' (O'Brien 2007: 416). The mother agrees with him, takes 'a bucket full of muck, mud and ashes and hen's droppings' back in to the house to arrange an environment where her son could be brought up 'according to the old Gaelic tradition' (O’Brien 2007: 416). O’Brien thus explicitly points to the reader the sources he draws upon while making it clear that they are to be ridiculed in his novel. The use of the phrase 'eminently describable' points to

3 Corkadoragha in Power's translation.

4 Sometimes referred to simply as Old-Fellow. 
an awareness of a certain literary convention which is later denoted by the phrase "good Gaelic books". The counter-commonsensical absurdity of spreading the swept-out dirt around the house for a child to be put in it clearly indicates the extent of the liberties that will be taken to mock that convention. The repetition of the smallness and lime-whiteness for the exterior of the house and its location on the right-hand side as one goes eastwards along the word for both the protagonists' house and the typical house the Gaels in books always lived in directs the readers' attention to how much that convention produces literary clichés and real-world stereotypes with regards to how the 'true Gaels' are housed.

When the house's location and exteriors are discussed later on the narrator states: 'Doubtless, neither my father nor any of his people before him built the house and placed it there; it is not known whether it was god, demon or a person who first raised the halfrotten, rough walls' (O'Brien 2007: 416) ${ }^{5}$. Anne Clissmann notes that the way the house is in a true stage-Irishman fashion, housing the animals and the humans in an odoriferous cohabitation' (Clissmann 1975: 241) can be read as an intertextual reference to Ó Criomhthain who writes describing his house: 'We had a post bed in the corner, and two beds at the bottom of the house. There used to be two cows in the house, the hens and their eggs, an ass, and the rest of us' (O'Crohan 1978: 2). Clissmann points out that O'Brien 'not to be outdone, crams his house with, in good times, »two cows, a cart-horse, a race-horse, sheep, pigs, and other lesser animals«' (Clissmann 1975: 241). The 'good times' are the OldGrey-Fellow's memories of his youth. In Bonaparte O'Coonassa's narrative of his own childhood the whole passage concerning beds and animals is parodied. O'Brien writes:

Yonder a bed with pigs upon it; here a bed with people; a bed there with an aged slim cow stretched out asleep on her flank and a gale of breath issuing from her capable of raising a tempest in the centre of the house, hens and chickens asleep in the shelter of her belly; another bed near the fire with me on it. Yes! people were in bad circumstances when I was young and he who had stock and cattle possessed little room at night in his own house. Alas! It was always thus. (O’Brien 2007: 417)

Also the very structure of Ó Criomhthain's sentence with the animals coming first and "the rest of us" placed at its end seems to be satirized in The Poor Mouth. The Old-GreyFellow recounts a story from his youth about a lost school-inspector who arrived at the house in bad weather. The gentleman was appalled to find the animals inside the house and advices the Old-Grey-Fellow to build a hut at the side of the yard to put an end to the shameful cohabitation with 'the brute beasts'. The Old-Grey-Fellow follows his advice and with the help of his neighbours builds such a hut only to move into it himself with his grandmother and his two brothers as it never occurs to him that the gentleman meant it to be built for the animals.

In Bonaparte's lifetime animals' precedence over human inhabitants of the house takes a different form. Chapter 2 describes the story of Ambrose, a pig which was kept in the house all the time and bottle-fed by Old-Grey-Fellow after he had realised the piglet was too 'shy' to outrun its siblings to reach the mother's breast. The pig smelled particularly bad; the narrator notes: 'My mother and the Old-Fellow often arose and went out-side to walk ten miles in the rain to escape from the stench' (O’Brien 2007: 421). After some time

5 The sentence recalls The Tale of Black Peter and the priest's explanation that it was not god but two Dublinbased authors who created the reality the characters found themselves in. 
the mother, ill due to the reek, threatens to set the house on fire if Old-Grey-Fellow does not get Ambrose out of it. He refuses at first but after a long argument agrees to eject Ambrose. When he tries, however, it turns out that the pig has grown too big to fit through the door. The mother carries out her threat and sets the house ablaze but the Old-GreyFellow manages to put the fire out in time. Her condition gradually worsens to the point when she bids goodbye to the family as she expects to die and the Old-Grey-Fellow needs to take her bed outside of the house in order to save her. The following day the rest of the beds are taken out as well and the family intends to live outside the house henceforth as the Old-Grey-Fellow cannot think to kill Ambrose. The execution is eventually carried out by Martin O'Bannassa who passes by the house one day but until that time it is clear that the pig preponderates over the people in that place. As the story unfolds, the human inhabitants' position gradually deteriorates to the point of absurdity and thus the absurdity of the readers' expectations regarding the depiction of the everyday life in Gaeltacht is exposed and satirized.

Other than nearly killing the narrator's family, the stench also drove the neighbours away; an event relevant not only to presenting the geography of the fictional world of this one particular novel, but also to establishing intertextual links with Gaeltacht memoirs. The narrator states: 'There was another house two hundred yards down the road from us and one day when our smell was extremely bad the folks there cleared out, went to America and never returned' (O'Brien 2007: 419). The fragment presents the area as having a very sparse population despite the house being set in a village and, more importantly, touches upon a subject of a major importance to Irish history and culture and the Irish-speaking community in particular — the emigration to America. Farnon notes: 'Emigration was always a very real fact of life in the Gaelic autobiographies. The primitive economy of the region could not possibly support all its natives. In An Béal Bocht O'Nolan provides an alternative reason for the mass emigration. The economic motives behind the phenomenon are totally jettisoned' (Farnon 1997: 98). In a highly subversive manner O'Brien draws the readers' attention to a fact of history recorded in the memoirs, and one that a reader might expect to be addressed by that kind of writing, and uses it in a trivial and ostentatiously unrealistic story to produce a satiric effect based on the tension between the readers' expectations and the story that is being offered to them.

The Poor Mouth's most evident play on the geographies of Irish literature, however, comes with the creation of the village of Corcha Dorcha. Farnon notes on the name itself: 'In O'Nolan's choice of word he conjures up the very essence of the region he describes and that of the entire book. Dorcha being the Gaelic word for »dark«, embodies connotations of doom, gloom, precipitation and perennial potato-eating' (Farnon 1997: 90). The name, as Farnon also notes, rhymes, which adds to the playful aesthetic effect, and, more importantly, recalls to the readers' minds the actual place name Corca Dhuibhne, a Gaeltacht area in County Kerry which includes the Blasket Islands. Of that Farnon writes: 'Corca Dhuibhne is a relatively small Gaeltacht area (...) and yet it managed to produce a "profusion" of literature. The autobiography was to become the fashionable literary genre in this region' (Farnon 1997: 90). The most notable works produced in the region include the already mentioned Ó Criomhthain's An tOileánach (1929), Maurice O'Sullivan's Fiche Blian ag Fás (1933) and Peig Sayers's Peig (1936). With Ó Criomhthain's being the 
pioneer of these, The Poor Mouth, which first came out in 1941, had more than a decade's worth of writing to refer to.

It is blatantly obvious that O'Brien's Corcha Dorcha is not a real or even a realistically represented space. This is how the narrator describes the view from the house's two windows and the door set between them:

Looking out from the right-hand window, there below was the bare hungry country-side of the Rosses and Gweedore; Bloody Foreland yonder and Tory Island far away out, swimming like a great ship where the sky dips into the ocean. Looking out of the door, you could see the West of County Galway with a good portion of the rocks of Connemara, Aranmore in the ocean out from you with the small bright houses of Kilronan, clear and visible, if your eyesight were good and the Summer had come. From the window on the left you could see the Great Blasket, bare and forbidding as a horrible other-worldly eel, lying languidly on the wave-tops; over yonder was Dingle with its houses close together. (O’Brien 2007: 418)

The description covers most of the Gaeltacht area where Gaelic literature is, and potentially could be, set in. And since it is a rather large area, it betrays the improbability of the place as no house could possibly have that view ${ }^{6}$. In The Poor Mouth Gaeltacht areas form one conjunct place the whole of which can be overseen from a single house. The same effect is achieved with the description of the pupils from the school to which the narrator goes at the age of seven: 'Many were from Dingle, some from Gweedore, another group floated in from Aran' (O'Brien 2007: 242) and the narrator's and/or the Old-Fellow's journeys supposedly carried out on foot: 'The Old-Fellow was one day in Dingle (...) The next day he was selling herrings in the Rosses (...) The third day he was in Galway city (...)' (O’Brien 2007: 426). Neil Murphy notes that O'Brien is 'diminishing the size of the country to a cardboard cut-out' (Murphy 2014: 151). The real world geography is radically distorted in the novel and replaced by an anti-mimetic creation of space which corresponds to the simplified vision readers based outside of Gaeltacht may have of the place. O'Brien, Murphy notes, is 'transforming the physical locus into a comic textual copy' (Murphy 2014: 151).

While The Poor Mouth lays the fictionality of Corca Dorcha bare and indulges in it, Poor Things engage in a different game. Glasgow is real. It is not, however, a generic location for a Gothic novel and for a long time it has hardly been thought of as a suitable location for any kind of fiction writing at all. Liam McIlvanney notes that: 'It has sometimes seemed that, apart from a brief flurry of "proletarian« novels in the 1930s, there has been, in literary terms, an »urbane silence« about Scotland's largest city until the early 1980s, when »Glasgow Renaissance« galvanised contemporary Scottish literature with its potent fusion of vernacular energy, formal innovation and generic eclectism' (McIlvanney 2012: 218).

Like O'Brien in The Poor Mouth, Gray begins his book with an introduction by an editor who makes an allegedly authentic autobiographical account of someone's life available to the reading public. But unlike O’Brien, Gray himself plays the editor part using his name to authenticate a glaringly inauthentic story. And it is a part undermin ed in the very first paragraph where Gray writes: 'Those who examine the proofs given at the end of this introduction will not doubt that in the final week of February 1881, at 18 Park Circus,

6 Tory Island is situated off the north-west coast of Ireland; Dingle is in the south-west of the island with nearly 500 kilometres between them. 
Glasgow, a surgical genius used human remains to create a twenty-five-year-old woman. The local historian Michael Donnelly disagrees with me' (Gray 1993: IX) ${ }^{7}$. The elaborate game of establishing and subverting the authority that could decide the probability of the events presented in the narrative attributed to Archibald McCandless which begins here is one thing. But what is more important for the purposes of a space-oriented analysis is that in the expositional first paragraph a place is thematised which is both the central location of the fictional narrative (yet to be presented to the reader) and an actual valid real-life Glasgow address.

The next paragraph, which is supposed to explain to the reader how Michael Donnelly found the manuscripts on the authenticity of which he disagrees with Alasdair Gray, opens with 'Life in Glasgow was very exciting during the nineteen seventies' (Gray 1993: IX) and goes on to describe Glasgow to a much greater extent than it does describe Michael Donnelly's presence in it. The paragraph on page XII, which describes what has happened between him acquiring Archibald McCandless's book and his wife's letter which debunks it and Alasdair Gray's allegedly becoming involved in the story, illustrates that rather well. The readers learn that on the very same afternoon Donnelly found the documents he also:

learned that Glasgow University's old theological college was being cleared out for renovation by a firm of property developers. (It is now luxury flats.) Michael found it contained over a dozen large framed oil paintings of eighteenth- and nineteenth-century Scots clergy, and these too would have burned in the municipal incinerator at Dawsholm Park if he had not cut them from their stretchers (they had been screwed to the wall at a prominent height) and taken them to the municipal gallery in Kevingrove, where space was found for them in the overcrowded store. (Gray 1993: XII)

The events which are not likely to seem relevant to the story presented in Poor Things recall places that actually exist in Glasgow, an intervention that both seemingly authenticates the story told and thematises Glasgow as such, the fact that the 1970s saw the buildings of Trinity College buildings in Lynedoch Street, Park Circus, sold and abandoned (MacLean 2012) adding another link to the narrative's central location, 18 Park Circus. The address then features more prominently in paragraphs which follow this one. In them Alasdair Gray (or, to be more precise, an Alasdair Gray's figure) lists the events that were allegedly proved to be true by the research conducted by Gray. The events present a short summary of what will be later elaborated on in McCandless's first-person-narrated part of Poor Things. The list comprises mainly of events that fit snugly into the Gothic conventions: a young woman's dead body found and never claimed, an extraordinary noise heard, a man being locked up in a lunatic asylum, another man committing suicide, and yet another man buried in a 'uniquely shaped coffin' (Gray 1993: XIV-XV) which all come with this (18 Park Circus) or another valid Glasgow address.

Obviously, beginning a book with a fictional editor's introduction is not, strictly speaking, a Gothic novel convention. Not all Gothic novels use that framing device and not all novels using it are Gothic. But it surely carries with it the whiff of that part of the literary past when Gothic novels were idiomatically created. Considering the linear progression

7 Aware of the editorial conventions, Gray uses roman numerals for page numbers of the introduction which give it a feel of something that stands apart from the narrative which follows it. 
of the narrative, it is only likely to be recognised as 'Gothic' once the Gothic aspect of the story has been fully communicated to the reader. Once it is however, one cannot help but miss how little relevance there is in recalling Glasgow's being the European Capital of Culture in 1990, as is done later in the paragraph cited above, for the Gothic story part of the novel and just how relevant it is to thematising the modern-day city of Glasgow.

The beginning of the second chapter of McCandless book, i.e. the Gothic narrative proper, sees Gray use a more idiomatically Gothic space. The chapter introduces Godwin Baxter, the alleged Frankenstein figure of the novel. His name, Kirsten Stirling argues, 'not only has the convenient abbreviation 'God', but is also stitched together from parts of William Godwin, her father, Percy Bysshe Shelley, her husband, and William Baxter (less obviously perhaps), the father of the family in Dundee with whom Mary Shelley was sent to stay at the age of fifteen" (Stirling 2008: 92). The chapter begins with a statement that McCandless, then a student of the Glasgow medical faculty, knew Baxter by sight for three terms, before they first spoke to each other. Then it moves on to presenting Baxter:

A private workspace had been made in the corner of the dissecting-room by taking a door off a cupboard and installing a bench. Baxter usually sat there (...) and here his big face, stout body and thick limbs gave him a dwarfish look. Sometime he ran out to raid the tank disinfectant where brains were heaped like cauliflowers, and as he passed other people you saw he was a whole head taller than most. (Gray 1993: 12)

This grotesque presentation continues with epithets such as 'ogreish' and 'odd' and an orientalised remark by McCandless that he felt Baxter would 'look more natural in the baggy pants and turban of a pantomime Turk' (Gray 1993: 12); it's very clear aim is to create a freakish character. What is perhaps less strikingly visible at first glance is that space is also used to establish that effect. The private workspace separates Baxter from other students and it is 'here' where he is given the 'dwarfish look' and it is his movement through the room that reveals him being so unnaturally taller than most people. The fact that it is a dissecting room accessorised with tanks with brains Gothicise the space and the interplay of the space and Godwin Baxter's features form an impression of a credibly Gothic narrative.

The next chapter introduces Baxter's home at 18 Park Circus. 'It was a tall, gloomy house in Park Circus' (Gray 1993: 22), we first learn of it. McCandless and Baxter are welcomed by the latter's dogs, then go through the basement into a 'narrow garden with high walls' where Baxter keeps two rabbits he intends to show to McCandless. While a tall, gloomy house with a basement seems Gothic enough, a garden with rabbits in it might not if it was not for the fact that the rabbits were half-white and half-black each in manner that is soon to be revealed a result of Baxter's cutting two rabbits into halves and sawing the front part of each to the bottom part of the other one. The conversation that arises from that presentation deals with the possibilities of using similar techniques on humans. Although the tone of that exchange is more discussing modern day politics than it is uncanny, it still alludes to the competences of one of the Gothic genre's most iconic doctors, Dr Frankenstein. The two characters end up falling out with each other. As McCandless is accompanied to the door, he passes by the dogs again who 'sprawled upon Persian rugs' apparently sense 'their master's hostility' which makes them freeze in a sphinx-like positions (again, an orientalised description). He also notes 'In the stairwell above I sensed rather than I glimpsed a head in a white cap staring down over the banis- 
ters of a landing, perhaps an ancient housekeeper or maidservant' (Gray 1993: 25) which adds another Gothic-like mystery to the story.

Chapter 4 brings a change. The second sentence informs the reader that Baxter no longer comes to the University and the third that his workplace has been dismantled and turned back into a cupboard. The place that might have suggested itself important to the readers disappears from the narrative altogether. Baxter's house changes as well. McCandless is invited there after reuniting with Baxter whom he met while walking up Sauchiehall Street (again, a valid Glasgow location). He describes the room he visits:

It had tall windows overlooking the Circus, a bright fire under a marble mantelpiece. (...) Through an open double door I saw a room overlooking the back garden, and by the fire in this room a placid elderly lady sat knitting, a small boy played with toy bricks at her feet, two rabbits sipped milk from a saucer. Baxter murmured that the lady was his house keeper, the boy her grandson. One rabbit was pure black, the other pure white but I decided to draw no fantastic conclusion from this. (Gray 1993: 28)

The place thus goes from 'gloomy' to having tall windows and a bright fire, the confinement suggested by the basement and a narrow garden between high walls is replaced by the narrator being able to see through open double door and a window, the mysterious 'ancient' woman is as homely as can be, and the rabbits are back to normal. What does appear strange to McCandless is that the place is clustered with various objects which he lists. The list is rather long and very diverse beginning with a telescope and ending, after many un-weird items such as a fully furnished doll's house have been named, with 'glass jars holding pickled limbs and bodily organs' (Gray 1993: 29). These certainly bring back the sense of a Gothic location but the narrator is quick to add a disclaimer: 'their brown morbidity was contradicted by surrounding vases of daffodils, pots of hyacinths and a great crystal bowl in which a tiny, jewel-like tropical fish darted and large golden ones glided' (Gray 1993: 29). Gray thus creates a self-contradictory space which signals Gothic conventions but is quick to subvert them.

It is on this occasion McCandless meets Bella Baxter, the Frankenstein's monster of the novel; a woman Baxter created and McCandless will eventually marry. Her character has been much discussed for what she and her adventures represent and how her search of identity can be identified with the search of Scotland's own (cf. Stirling, Kaczvinsky, March). Kaczvinsky suggests that:

an identification between Bella and Scotland is at the very heart of Gray's novel. Bella's loss of memory, the loss of her past, impedes any attempt to put together a clear, coherent self, and her search for a personal becomes a metaphor for Scotland's postmodern search for a national identity, especially in the late twentieth century, as its ties to England are severed. (Kaczvinsky 2001: 776)

Such identification is very much advertised by Gray himself who inserts a portrait of Bella Baxter (most central characters are introduced with portraits in the book) signed as 'Bella Caledonia'. Bella thus represents the nation but, as Stirling notes, 'the Frankenstein-esque plot of Poor Things ensures that Bella can never be an uncomplicated representation of nation' (Stirling 2008: 88). Since identity as such is not really the scope of this paper and the discussion about it too extensive to be summarized in a conveniently short form, we 
may resort to a rather reductive recapitulation that captures the interplay of the genre conventions and the representation of place: an iconic Gothic plot is used in Poor Things to represent a country. The fact that the monster in Gray's book is a beautiful woman gradually exploring her sexuality naturally adds other dimensions to the act of retelling Shelley's story.

Though it would be too bold to argue that it was the strong relationship to space inherent in the Gothic genre that was the main inspiration behind Gray's choice of the convention to be parodied, this relationship certainly does accommodate the discussion of space-related issues such as Scottish identity quite well. The operations performed in the Baxter's private workspace (establishing a space only to discard it) and the house at 18 Park Circus (creating a hybrid space that sometimes meets and sometimes subverts the readers' genre-driven expectations) open the reader up to a discussion on how hybrid Glasgow and the whole of Scotland are. Additionally Gray takes advantage of the nonspatial elements of the Gothic convention to renegotiate the traditional notion of the personification of a country/nation. The familiarity of the Frankenstein's monster and its obvious affiliation to a much conventionalised genre enable Gray to deal with that without the reader's attention dwelling on the question where the idea of a dead body brought back to life by a doctor came from.

In O'Brien's case parodying a genre while making a statement about the representation of a region and the production of national identity seems a much more obvious choice considering the character of the genre parodied. What is less obvious given the time of its publication is the overt self-reflectiveness of the narrative which reveals to the reader the fictionality of the book and the literary sources that inspired it. Though not as wildly experimental as At Swim-Two-Birds, which granted O'Brien the status of a precursor of postmodernism, The Poor Mouth is still a striking intervention into the literary conventions of the time. It is a metafictional novel heavily loaded with intertextual references and, as Joseph Brooker notes, 'a reinscription of a genre' (Brooker 2005: 65). And as in Poor Things, representations of place are often used in it as vehicles for the literary operations.

'All parody is overtly hybrid and double-voiced', Hutcheon notes (Hutcheon 1986: 28), and so are the places represented by Gray and O'Brien. Both authors set out to parody a genre that is (or should be) considered unrealistic in its portrayal of the real world and both engage in an exercise of layering fiction upon fiction. But the overt fictitiousness of their work and the self-contradiction embodied in it takes the reader back to the reality outside of literature. The Poor Mouth and Poor Things both call for a reassessment of literary representations of place and the local identities derived from those representations and both do so by playing seemingly intra-literary self-referential games of parodying genre convention. 


\section{Bibliography}

Bigsby Christopher W.E. (2006), Gothic [in:] this, The Routledge Dictionary of Literary Terms, Routledge, Oxon-New York.

Brooker Joseph (2005), Flann O’Brien, Northcote House, Tavistock.

Clissmann Anne (1975), Flann O'Brien: A Critical Introduction to His Writings, Gill and Macmillan, London.

Cuddon John A. (2013), Gothic Novel/ Fiction [in:] this, A Dictionary of Literary Terms and Literary Theory, Wiley-Blackwell, Chichester.

Dentith Simon (2000), Parody, Routledge, London-New York.

Farnon Jane (1997), Motifs of Gaelic Lore and Literature in An Béal Bocht [in:] Conjuring Complexities:

Essays on Flann O'Brien, eds. A. Clune, T. Hurson, The Institute of Irish Studies, Belfast.

Genette Gérard (1997), Palimpsests: Literature in the Second Degree, trans. C. Newman, C. Doubinsky, University of Nebraska Press, Lincoln-London.

Gifford Douglas (2002), Scottish Fiction since 1945 II: Despair, Change and Hope [in:] Scottish Literature: In English And Scots, eds. D. Gifford, S. Dunnigan, A. MacGillivray, Edinburgh UP, Edinburgh.

Gray Alasdair (1985), Lanark: A Life in Four Books, Panther, London.

- (1993), Poor Things: Episodes from the Early Life of Archibald McCandless M.D., Scottish Public Health Officer, Penguin, London.

Hodrová Daniela (1997), Pamèt’ a promèny mist: Na okraj tematologie a topologie [in:] Poetika mist: kapitoly z literárni tematologie, ed. D. Hodrová, H \& H, Praha.

Hutcheon Linda (1985), A Theory of Parody: The Teachings of Twentieth-Century Art Forms, Methuen, New York.

Kaczvinsky Donald P. (2001), "Making up for Lost Time": Scotland, Stories, and the Self in Alasdair Gray's "PoorThings", "Contemporary Literature” 42.4.

MacLean Robert, Trinity College Image: Search for the Holy Grail? "University of Glasgow Library" Web. 2 October 2012, https://universityofglasgowlibrary.wordpress.com/2012/10/02/trinitycollege-image-search-for-the-holy-grail/ [access: 25.02.2017].

March Cristie (2002), Bella and the Beast (and a Few Dragons, Too): Alasdair Gray and the Social Resistance of the Grotesque, "Critique: Studies In Contemporary Fiction" 43.4.

McIlvanney Liam, The Glasgow Novel [in:] The Cambridge Companion to Scottish Literature, eds. G. Carruthers, L. McIlvanney, Cambridge UP.

Murphy Neil (2014), Myles Na gCopaleen, Flann O'Brien and An Béal Bocht: Intertextuality and Aesthetic Play [in:] Flann O’Brien: Contesting Legacies, eds. W. Huber, R. Borg, P. Fagan, Cork UP, Cork. Ó Crohan Tomás (1978), The Islandman, trans. R. Flower, Oxford UP, Oxford, New York.

O'Brien Flann (2007), The Poor Mouth [in:] The Complete Novels, F. O’Brien, trans. P. Power, Alfred A. Knopf, New York.

- (2013), The Tale of Black Peter [in:] The Short Fiction of Flann O'Brien, eds. K. Hopper, N. Murphy, trans. J. Fennell, Dalkey Archive Press, Champaign.

Riach Alan (2014), The Literary Vision or How to Make Things Seen [in:] Alasdair Gray: Ink for Worlds, ed. C. Manfredi, Palgrave Macmillan. Basingstoke.

Stirling Kirsten (2008), Bella Caledonia: Woman, Nation, Text, Rodopi, Amsterdam.

Taaffe Carol (2008), Ireland Through the Looking-Glass: Flann O'Brien, Myles Na gCopaleen and Irish Cultural Debate, Cork UP, Cork. 